\title{
PHYSICAL CHARACTER OF KAMPUNG SETU BABAKAN, SOUTH JAKARTA, AS BETAWI CULTURAL HERITAGE REGION
}

\author{
${ }^{1}$ Yoana Wardana. ${ }^{2}$ Dr. Ir. Y. Basuki Dwisusanto, M.Sc. \\ ${ }^{1}$ Student in the Bachelor's (S-1) Study Program in Architecture \\ at Parahyangan Catholic University \\ 2 Senior lecturer in the Bachelor's (S-1) Study Program in Architecture \\ at Parahyangan Catholic University
}

\begin{abstract}
Setu Babakan town which is located in Srengseng Sawah political districts, Jagakarsa sub-district, South Jakarta, is a region of settlement that are established as Betawi cultural heritage. This research discusses about representation of Betawi culture physical characters in Setu Babakan town. Culture characters could be faded with the advent of times due to lifestyle that has changes, but it could also be adhere with the awareness of the importance of preserving the existing culture.

This study attempts to know how far do the Setu Babakan physical characters as Betawi culture heritage districts reflects the physical characters of Betawi native culture, so it can be found which physical characters that is still retained, that modificated, and that are totally changed. In addition, can also be found how many buildings which is still retaining the whole physical heritage of Betawi culture, which only retaining some of the physical heritage of Betawi culture, and which are not retaining the physical heritage of Betawi culture at all.

Scope of this study was conducted throughout the area of Setu Babakan town so that the data be more accurate and to represent the overall condition of the area. The interview and questionnaire distribution was conducted to 21 respondents $(20$ respondents wich are Betawi ethnic and 1 respondent which is not Betawi ethnic, aged between 23-67 years old, islamist, with 3/4/5/6/10 family members)and the management of Setu Babakan town (Pak Buhori) to complement the data obtained through literature study and field observation about physical characters (buildings and outdoor layouts) and non-physical characters (rituality, social activities, religious, economic, abstinence, lifestyle, and education) of Betawi culture in Setu Babakan town and the physical and nonphysical characters of Betawi native culture. Data from the respondents, interior photo of respondent's house, and respondents photo have been permitted by the concerned parties to be published. The observation and recovery data was undertaken along January-march 2018. Physical characters data (existing condition) that was obtained through direct observation in the field are strengthened by matching it with the existing condition in google street to avoid mistakes/inadvertence in the process of field observation. Physical characters observation is conducted by seeing one by one building, to know the authenticity level of its physical characters of Betawi culture in every building. All of the observation results were recorded by doing mapping. This research is qualitative-quantitative research approach descriptive and cultural.

Analysis is conducted in descriptive and causal comparative approach qualitative-quantitative. The analysis begins by comparing the physical characters of Betawi native culture backed by the non-physical characters with physical characters of Betawi culture in Setu Babakan town backed by the non-physical characters. Then doing macro mapping (showing number of buildings that retained the overall of physical characters of Betawi culture, that retained some of them, and that totally changed) and micro mapping (showing which physical characters that still been retained, modificated, nor totally changed) to know how far did the physical characters of Setu Babakan town as Betawi culture heritage districts reflected the physical characters of Betawi native culture and to know the factors that influence it.

The research results show, the physical character application of Betawi culture in Setu Babakan town has faded, so it needs to be developed again. Not until $50 \%$ of the buildings retained the physical characters of Betawi culture.
\end{abstract}

Key Words: physical characters, Setu Babakan town, Betawi culture heritage districs, South Jakarta

\footnotetext{
${ }^{1}$ Corresponding Author: yoana290996@gmail.com
} 


\title{
KARAKTER FISIK KAMPUNG SETU BABAKAN, JAKARTA SELATAN, SEBAGAI KAWASAN CAGAR BUDAYA BETAWI
}

\author{
${ }^{1}$ Yoana Wardana. ${ }^{2}$ Dr. Ir. Y. Basuki Dwisusanto, M.Sc. \\ ${ }^{1}$ Mahasiswi S1 Program Studi Arsitektur Universitas Katolik Parahyangan \\ ${ }^{2}$ Dosen Pembimbing S1 Program Studi Arsitektur Universitas Katolik Parahyangan
}

\begin{abstract}
Abstrak- Kampung Setu Babakan yang berlokasi di kelurahan Srengseng Sawah, kecamatan Jagakarsa, Jakarta Selatan, merupakan kawasan permukiman yang ditetapkan sebagai cagar budaya Betawi. Penelitian ini membahas tentang representasi karakter fisik budaya Betawi di Kampung Setu Babakan. Karakter budaya dapat memudar seiring dengan perkembangan zaman akibat pola hidup yang telah berubah, namun dapat pula bertahan dengan adanya kesadaran akan pentingnya melestarikan budaya yang telah ada.

Penelitian ini bertujuan untuk mengetahui seberapa jauh karakter fisik Kampung Setu Babakan sebagai kawasan cagar budaya Betawi mencerminkan karakter fisik budaya asli Betawi, sehingga dapat ditemukan karakter fisik apa saja yang masih dipertahankan, yang mengalami modifikasi dan yang berubah total. Selain itu, dapat ditemukan pula berapa banyak bangunan yang masih mempertahankan keseluruhan karakter fisik budaya Betawi, yang hanya mempertahankan beberapa/sebagian karakter fisik budaya Betawi, dan yang sama sekali tidak mempertahankan karakter fisik budaya Betawi.

Lingkup penelitian dilakukan di seluruh kawasan Kampung Setu Babakan agar data lebih akurat dan dapat mewakili keseluruhan kondisi kawasan. Wawancara dan pembagian kuisioner dilakukan kepada 21 responden (20 responden beretnis Betawi dan 1 responden non-Betawi, berumur antara 23-67 tahun, beragama Islam, beranggota keluarga rata-rata 3/4/5/6/10 orang) dan pihak pengelola Kampung Setu Babakan (Pak Buhori) untuk melengkapi data yang didapatkan melalui studi literatur dan observasi di lapangan mengenai karakter fisik (bangunan dan tatanan ruang luar) dan non-fisik (upacara adat, kegiatan sosial, keagamaan, ekonomi, pantangan, pola hidup, dan pendidikan) budaya Betawi di Kampung Setu Babakan dan karakter fisik dan non-fisik budaya Betawi asli. Data yang didapat dari responden, foto interior rumah responden, dan foto responden sudah diizinkan oleh pihak yang bersangkutan untuk dipublikasikan. Pengamatan/observasi dan pengambilan data dilakukan dari bulan Januari-Maret 2018. Data karakter fisik (kondisi eksisting) yang didapatkan melalui observasi langsung di lapangan diperkuat dengan cara mencocokkan kembali kondisi eksisiting tersebut melalui google street untuk menghindari terjadinya kesalahan/ketidaktelitian dalam proses observasi lapangan. Pengamatan karakter fisik dilakukan dengan melihat satu per satu bangunan, untuk mengetahui tingkat keaslian karakter fisik budaya Betawi di setiap bangunan yang diteliti. Pencatatan keseluruhan hasil pengamatan direkam dengan melakukan pemetaan. Penelitian ini adalah penelitian kualitatif-kuantitatif dengan pendekatan deskriptif dan kultural.

Analisis dilakukan secara deskriptif dan kausal komparatif dengan pendekatan kualitatif-kuantitatif. Analisis dimulai dengan menbandingkan karakter fisik budaya Betawi asli yang didukung oleh karakter nonfisiknya dengan karakter fisik budaya Betawi di Kampung Setu Babakan yang didukung oleh karakter nonfisiknya. Kemudian dilakukan pemetaan secara makro (menunjukkan jumlah bangunan yang mempertahankan karakter fisik Betawi secara utuh, yang mempertahankan hanya sebagian, dan yang berubah secara total) dan secara mikro (menunjukkan karakter fisik apa saja yang dipertahankan, mengalami modifikasi, maupun berubah secara total) untuk mengetahui seberapa jauh karakter fisik Kampung Setu Babakan sebagai kawasan cagar budaya Betawi mencerminkan karakter fisik budaya asli Betawi beserta faktor-faktor yang mempengaruhinya.

Hasil penelitian menunjukkan, penerapan karakter fisik budaya Betawi di kampung Setu Babakan sudah pudar, sehingga perlu dikembangkan kembali. Tidak sampai 50\% bangunan mempertahankan karakter fisik budaya Betawinya.
\end{abstract}

Kata Kunci: karakter fisik, Kampung Setu Babakan, kawasan cagar budaya Betawi, Jakarta Selatan

\section{PENDAHULUAN}

Kampung kota sebagai bagian dari kota ikut berperan dalam pembentukan identitas kota. Identitas kota dapat diwujudkan dengan adanya cagar budaya yang telah ditetapkan oleh 
pemerintah melalui peraturan daerah. Cagar budaya penting untuk melestarikan budaya setempat yang terancam punah seperti budaya Betawi. ${ }^{2}$

Dengan terdapatnya peraturan untuk melestarikan budaya Betawi dan terdapatnya kantor pengelola di Kampung Setu Babakan, memungkinkan kawasan Setu Babakan akan dikembangkan terus-menerus, namun perkembangan tersebut pada kenyataannya dapat menjadi ke arah yang lebih positif ataupun ke arah yang lebih negatif dibandingkan keadaan sebelumnya, bagi pelestarian budaya Betawi. Oleh sebab itu, penelitian tentang karakter fisik Kampung Setu Babakan, Jakarta Selatan, sebagai kawasan cagar budaya Betawi menjadi penting untuk mengetahui seberapa jauh karakter fisik Kampung Setu Babakan tersebut mencerminkan karakter fisik budaya asli Betawi, sehingga dengan mengatahui fakta yang ada, Kampung Setu Babakan dapat semakin dikembangkan lebih optimal/maksimal sebagai perkampungan budaya Betawi.

\section{KAJIAN TEORI}

Budaya Betawi merupakan akulturasi dari berbagai macam budaya seperti budaya Sunda, Melayu, Cina, Ambon, Makassar, Bugis, Bali, dan Arab. ${ }^{3}$ Budaya Betawi memiliki ciri khas pada karater fisik (bangunan berupa teras dan langkan, bentuk bangunan, ornamen, elemen struktural dan non-struktural serta tatanan ruang luar berupa pekarangan $)^{4}$, dan non-fisiknya (upacara adat, kegiatan sosial, kegiatan ekonomi, kegiatan keagamaan, pantangan, pola hidup, dan tingkat pendidikan) ${ }^{5}$. Budaya tersebut tumbuh dan berkembang di Jakarta dan lambat laun mulai pudar seiring perkembangan zaman. Besarnya arus urbanisasi dan perkembangan teknologi mempermudah arus globalisasi sehingga mempengaruhi pola hidup dan gaya hidup masyarakat. Pembangunan kota yang tidak mempertimbangkan pelestarian budaya juga menjadi pemicu menurunnya eksistensi budaya betawi. Penduduk kota yang heterogen dapat berdampak buruk bagi kelestarian budaya Betawi. Melihat perubahan yang telah terjadi, Dewan Pengurus Badan Musyawarah Masyarakat Betawi (BAMUS BETAWI) menetapkan beberapa peraturan untuk melestarikan budaya betawi yaitu Peraturan Daerah Provinsi Daerah Khusus Ibukota Jakarta Nomor 4 Tahun 2015 Tentang Pelestarian Kebudayaan Betawi, Peraturan Gubernur Provinsi Daerah Khusus Ibukota Jakarta Nomor 229 Tahun 2016 Tentang Penyelenggaraan Pelestarian Kebudayaan Betawi, dan Peraturan Gubernur Provinsi Daerah Khusus Ibukota Jakarta Nomor 11 Tahun 2017 Tentang Ikon Budaya Betawi ${ }^{6}$. Peraturanperaturan tersebut diwujudkan dengan keberadaan Kampung Setu Babakan sebagai permukiman cagar budaya Betawi. Kampung ini terletak di kelurahan Srengseng Sawah, kecamatan Jagakarsa, Jakarta Selatan. Terpilihnya Kampung Setu Babakan sebagai kawasan cagar budaya Betawi dipertimbangkan dari beberapa potensi di kawasan, seperti kawasan yang masih asri, masih terdapatnya beberapa masyarakat yang beretnis Betawi yang menetap di kawasan tersebut beserta beberapa rumah tradisional Betawi milik masyarakat tersebut [Buhori, 2018:02].

\footnotetext{
${ }^{2}$ SAFARI. 2016. Budaya Betawi Nyaris Musnah, Pemerintah Ditunding Lakukan Genoside. [Online]. Available: http://megapolitan.harianterbit.com/megapol/2016/04/08/59698/18 /18/Budaya-Betawi-NyarisMusnah-Pemerintah-Dituding-Lakukan-Genoside. [25 Mei 2018]

${ }^{3}$ AMAL, M. Ichlasul. 1999. Perkembangan Arsitektur Rumah Tinggal Betawi. Disertasi tidak diterbitkan. Bandung: Universitas Katolik Parahyangan.

${ }^{4}$ DR. ARIE BUDHIMAN, M.SI. 2012. Kajian Pengembangan Ornamen Betawi. Jakarta: Dinas Pariwisata dan Kebudayaan Provinsi DKI Jakarta.

${ }^{5}$ ISMET B. HARUN, K. HISMAN. 1991. Rumah Tradisional Betawi. Jakarta: Dinas Kebudayaan Daerah Khusus Ibukota Jakarta.

${ }^{6}$ PEMERINTAH DAERAH. 2017. Pelestarian Kebudayaan Betawi. Jakarta: Dewan Pengurus Badan Musyawarah Masyarakat Betawi [BAMUS BETAWI].
} 


\section{METODA PENELITIAN}

Untuk mencapai tujuan penelitian tersebut, proses membandingkan karakter fisik (yang didukung dengan karakter non fisik) budaya Betawi di Kampung Setu Babakan dengan karakter fisik Budaya Betawi asli menjadi permulaan dilakukannya analisis. Kemudian hasil perbandingan tersebut direkam melalui pemetaan. Penelitian ini menggunakan pendekatan kualitatif-kuantitatif dan metode deskriptif dan kultural berupa penjelasan deskriptif yang diperkuat dengan penyajian angka (jumlah bangunan) sebagai tolok ukur dari permasalahan yang diteliti.

\section{ANALISA}

\subsection{REPRESENTASI KAMPUNG BETAWI ${ }^{7}$}

Representasi kampung Betawi terbagi menjadi karakter fisik budaya asli Betawi dan karakter non-fisik budaya asli Betawi. Karakter fisik budaya asli Betawi terbagi menjadi tatanan ruang luar, tatanan ruang dalam, bentuk bangunan, elemen struktural dan nonstruktural, dan ornamen. Karakter non-fisik budaya asli Betawi terdiri dari keadaan sosial budaya dan pola hidup masyarakat Betawi dan asal usulnya (sikap terbuka terhadap pengaruh budaya luar), beberapa upacara dan pantangan (upacara adat berupa upacara pernikahan, sunatan, kematian, lebaran bersama, sedangkan pantangan berupa pantangan saat mendirikan rumah berupa sesajen yang diletakkan di atas tiang kolom, perhitungan hari baik dan menghindari "Naga Besar" saat membangun rumah), dan kegiatan sosial (arisan dan berkumpul bersama), kegiatan ekonomi (bertani, berdagang, dan nelayan), kegiatan keagamaan (berhubungan dengan agama Islam), dan tingkat pendidikan (rendah).

Tatanan ruang luar terbagi menjadi pekarangan bagian luar dan dalam. Pekarangan bagian luar memiliki ciri-ciri dekat dengan jalan, berjajar menghadap jalan, pekarangan/kebun terpisah dengan rumah, dan pembatas antar rumah berupa pohon (lihat figur 1). Pekarangan bagian dalam memiliki ciri-ciri jauh dari jalan, persebaran bangunan tidak beraturan, pekarangan/kebun menyatu dengan rumah, pembatas antar rumah berupa pohon (lihat figur 1). Keduanya memiliki pekarangan yang luas. Tidak ada ketentuan khusus pada pola tatanan masa rumah tradisional Betawi. Rumah-rumah Betawi tumbuh dan berkembang secara individual para pemilik lahan. Orientasi dan arah hadap rumah lebih dipengaruhi oleh pertimbangan bentuk, orientasi pekarangan, serta aksesibilitas menuju ke tapak. Fungsi-fungsi yang dibangun di atas pekarangan disesuaikan dengan kebutuhan pemilik rumah. Terjadi fragmentasi lahan akibat pembagian lahan sebagai warisan (lihat figur 2).

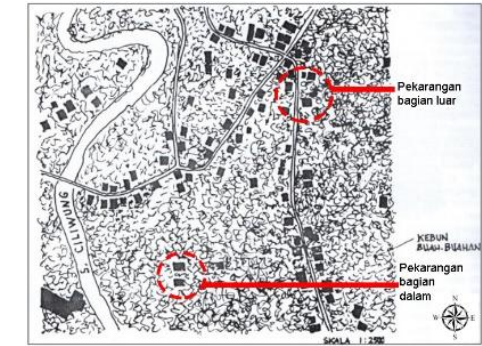

Figur 1. Pekarangan Betawi Bagian Dalam dan Luar

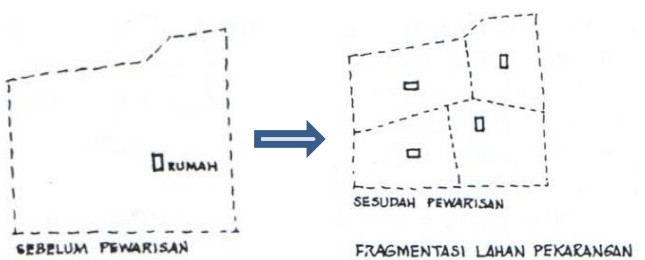

Figur 2. Fragmentasi Lahan Pekarangan Betawi

\footnotetext{
${ }^{7}$ ISMET B. HARUN, K. HISMAN. 1991. Rumah Tradisional Betawi. Jakarta: Dinas Kebudayaan Daerah Khusus Ibukota Jakarta.
} 
Tatanan ruang dalam bangunan umumnya terbagi menjadi 3 bagian, yaitu bagian depan (teras), tengah (r. tidur, r. makan, dan pendaringan), dan belakang (dapur) (lihat figur 3). Ornamen pada rumah tradisional Betawi terdiri dari lisplang gigi balang, ornamen pada kepala kolom, sekor, dan lain-lain (lihat figur 4).

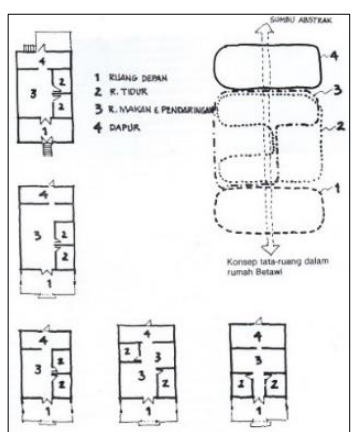

Figur 3. Variasi Tatanan Ruang Dalam Rumah Betawi

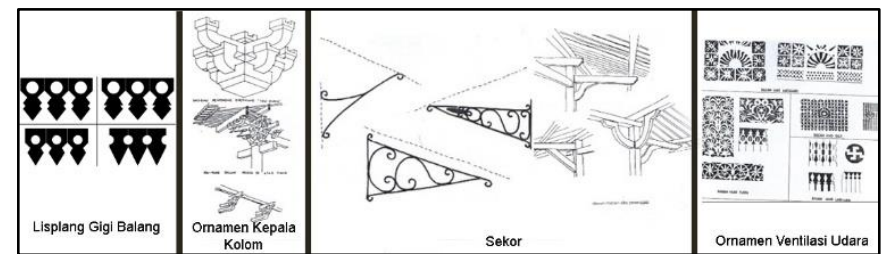

Figur 4. Ornamen-Ornamen Pada Bangunan Betawi

Elemen non-struktural bangunan Betawi terdiri dari jendela, pintu, dan perabot teras khas Betawi. Jendela pada rumah tradisional Betawi terbagi menjadi jendela bujang, jendela depan, jendela samping, dan jendela tanpa daun. Jendela bujang merupakan jendela dengan kisi-kisi lubang angin vertikal yang cukup lebar agar dapat digunakan untuk mengintip ke luar (biasanya digunakan oleh anak gadis untuk mengintip sambil mengobrol dengan calon laki-lakinya karena masyarakat Betawi sangat menjaga pergaulan anak perempuan. Jendela samping adalah jendela krepyak yang juga memiliki kisi-kisi lubang angin horizontal (lihat figur 5). Pintu utama rumah tradisional Betawi umumnya terdiri dari dua daun, terletak di tengah muka bangunan, berprofil, terbuat dari panil kayu, dan ada yang dikombinasi dengan bentuk krepyak. Pada bagian atas pintu terdapat ventilasi udara yang diberi hiasan bermotif (motif matahari/bunga matahari/bunga melati). Ornamen pada daun pintu umumnya berbentuk segiempat dengan takikan pada sudut-sudutnya (lihat figur 6). Perabot teras yang dimaksud adalah kursi, meja, bale-bale, dan lampu gantung. Perabot teras terbagi menjadi 2 set yang masing-masing setnya terdiri dari 4 kursi dan 1 meja. 1 meja berbentuk bulat (untuk menjamu tamu perempuan) dan 1 meja berbentuk persegi/bujur sangkar (untuk menjamu tamu laki-laki), lampu gantung Belanda, serta bale-bale (berupa kursi lebar dan panjang hampir seperti rangka kasur untuk bersantai, tiduran). Perabot teras terbuat dari kayu berwarna coklat tua. Alas meja ada yang menggunakan batu marmer. Lampu gantung berwarna putih dengan rangka berwarna hitam (dari besi) (lihat figur 7).

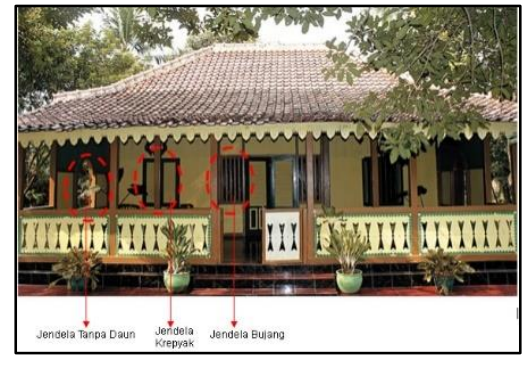

Figur 5. Jendela Khas Betawi

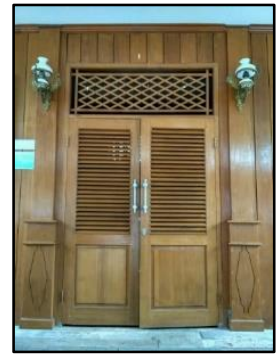

Figur 6. Pintu Khas Betawi

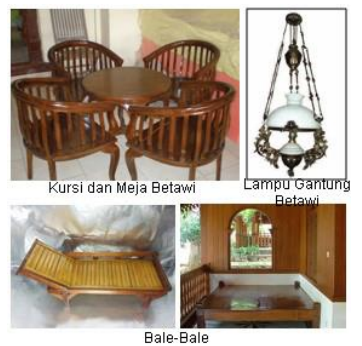

Figur 7. Perabot Teras Khas Betawi 
Bentuk bangunan rumah tradisional Betawi terbagi menjadi bentuk rumah bapang/kebaya, bentuk rumah kandang/gudang, dan bentuk umah joglo Betawi. Perbedaan antar bentuk bangunan terlihat dominan pada bentuk atapnya (lihat figur 8).

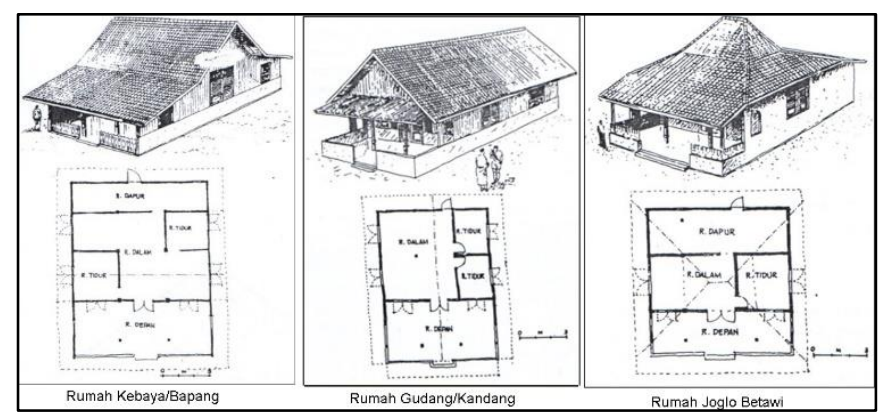

Figur 8. Bentuk-Bentuk Rumah Tradisional Betawi

Elemen struktural berupa kolom (tiang) baik yang di teras (tiang penyangga) maupun tiang utama bangunan (tiang guru) dilengkapi dengan pilaster kaki dan kepala kolom, ornamen bunga matahari pada bagian pinggang kolom, garis takik vertikal pada bagian kaki kolom. Kaki kolom lebih besar dibandingkan badan kolom dan umumnya menggunakan material kayu. Kolom berbentuk persegi/bujur sangkar dengan dimensi 10x10 cm atau 20x20 cm. Dimensi kolom dapat berbeda-beda pada tiap bangunan tergantung jarak antar tiang yang akan berpengaruh pada berat beban yang akan ditopang. Kolom-kolom yang terdapat pada sebuah rumah umumnya memiliki dimensi yang sama karena memiliki denah yang simetris dan bentuk yang sederhana. Warna kolom umumnya berwarna coklat muda atau coklat kekuningan (merupakan warna asli material kayu yang digunakan) (lihat figur 9).

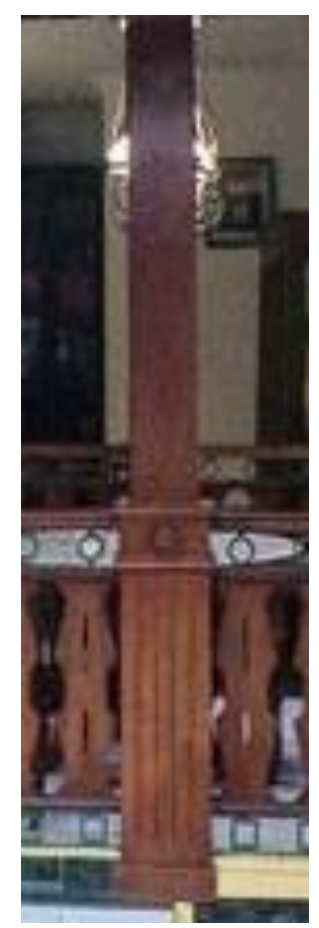

Figur 9.Kolom Khas Betawi 


\subsection{KAMPUNG SETU BABAKAN ${ }^{8}$}

Kampung Setu Babakan memiliki luas \pm 289 ha (5.961 bangunan). Kepemilikan lahan terbagi menjadi 4 yaitu, (1) milik masyarakat (seluas 214.5 ha atau 75\%), (2) milik Dinas PU/Pengairan (seluas \pm 64 ha), (3) milik Dinas Pariwisata \& Kebudayaan (seluas \pm 3,5 ha), dan (4) milik Dinas Pertamanan dan Pemakaman (seluas \pm 7 ha). Kepemilikan milik masyarakat yang lebih dominan dibandingkan lainnya mengakibatkan pembagian lahan dan pengolahan lahan tidak terkendali/terkontrol, terutama penerapan karakter fisik Budaya Betawi di kampung tersebut.

Pembangunan di Kampung Setu Babakan semakin hari semakin padat (ruang terbuka dan penghijauan semakin berkurang) (lihat figur 10). Hal ini disebabkan oleh pertumbuhan penduduk, urbanisasi, migrasi yang mengakibatkan kebutuhan akan hunian semakin meningkat, sehingga semakin banyak lahan kosong yang dimanfaatkan untuk pembangunan. Pola tatanan bangunan mengitari Setu Babakan (danau) yang menjadi bagian yang penting bagi kehidupan di permukiman. Dahulu, masyarakat yang tinggal di Kampung Setu Babakan memanfaatkan Setu Babakan (danau) sebagai sumber air yang digunakan sehari-hari dan tempat untuk pertambakan ikan. Saat ini, Setu Babakan (danau) dimanfaatkan sebagai tempat wisata air dan tempat untuk memancing.

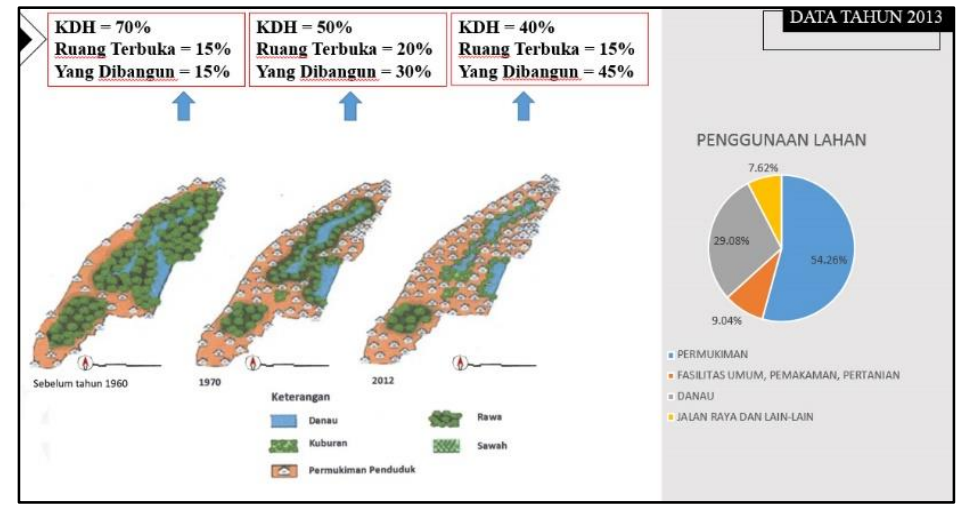

Figur 10. Perkembangan Penggunaan Lahan Kampung Setu Babakan

Area-area penting di Kampung Setu Babakan adalah area kantor pengelola Setu Babakan dan area embrio (lihat figur 11). Area kantor pengelola terletak pada area kawasan perkampungan Setu Babakan agar kegiatan mengontrol kondisi perkampungan tersebut menjadi lebih mudah. Area embrio merupakan area awal dikembangkannya karakter fisik budaya Betawi di Kampung Setu Babakan dan merupakan area yang paling banyak dan paling sering dikunjungi oleh para pengunjung/wisatawan. Area embrio dapat menjadi salah satu penentu pudar atau bertahannya budaya Betawi di sekitarnya.

\footnotetext{
${ }^{8}$ INDONESIA. Kantor Pengelola Setu Babakan. 2016. Paparan Perencanaan Perkampungan Budaya Betawi Setu Babakan Jakarta Selatan. Jakarta: Disertasi tidak diterbitkan.
} 


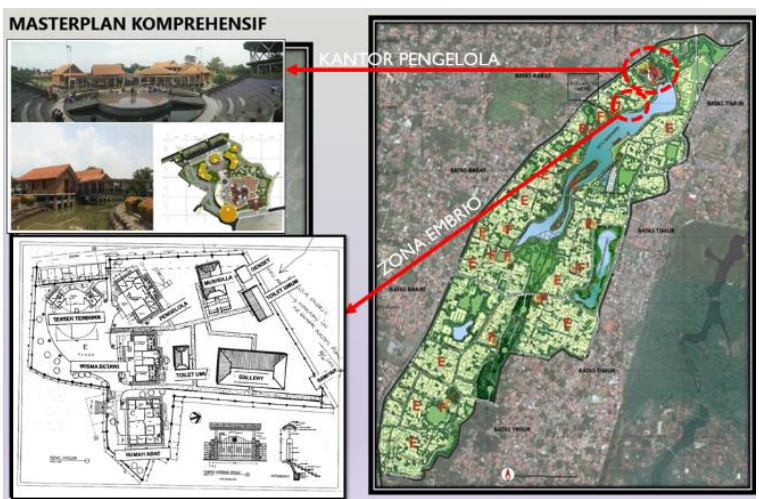

Figur 11. Area Penting Di Kampung Setu Babakan

Lingkup penelitian dilakukan di seluruh kawasan Kampung Setu Babakan agar data lebih akurat dan dapat mewakili keseluruhan kondisi kawasan. Wawancara dan pembagian kuisioner dilakukan kepada 21 responden. Analisis dilakukan secara deskriptif dan kausal komparatif dengan pendekatan kualitatif-kuantitatif. Analisis dimulai dengan menbandingkan karakter fisik budaya Betawi asli yang didukung oleh karakter non-fisiknya dengan karakter fisik budaya Betawi di Kampung Setu Babakan yang didukung oleh karakter non-fisiknya. Kemudian dilakukan pemetaan secara makro (menunjukkan jumlah bangunan yang mempertahankan karakter fisik Betawi secara utuh, yang mempertahankan hanya sebagian, dan yang berubah secara total) dan secara mikro (menunjukkan karakter fisik apa saja yang dipertahankan, mengalami modifikasi, maupun berubah secara total) untuk mengetahui seberapa jauh karakter fisik Kampung Setu Babakan sebagai kawasan cagar budaya Betawi mencerminkan karakter fisik budaya asli Betawi beserta faktor-faktor yang mempengaruhinya.

\subsection{KARAKTER FISIK BUDAYA BETAWI DI KAMPUNG SETU BABAKAN}

Karakter fisik Budaya Betawi di Kampung Setu Babakan dilihat secara makro dan mikro. Karakter fisik budaya Betawi secara makro terbagi menjadi yang dipertahankan (seluruh karakter fisik budaya Betawi masih terdapat pada bangunan tersebut) dan yang dimodifikasi (hanya sebagian karakter fisik budaya Betawi yang masih terdapat pada bangunan tersebut).

Dari 5.961 bangunan, hanya 10 di antaranya yang masih mempertahankan seluruh karakter fisik budaya Betawi (lihat figur 12). Dari 10 bangunan tersebut, 6 di antaranya terletak di kantor pengelola kampung Setu Babakan dan difungsikan sebagai tempat untuk merias dan berkumpul para penari adat sebelum mementaskan seni tari Betawinya. Pada saat tidak ada jadwal pementasan, bangunan-bangunan tersebut digunakan para pengelola untuk berkumpul dan mengobrol dengan para tamu/pengunjung. Pada area embrio, hanya 2 bangunan yang mencerminkan karakter fisik budaya Betawi secara utuh, yaitu wisma kampung Setu Babakan dan rumah Bu Sami. Tidak semua bangunan di area embrio mempertahankan keseluruhan karakter fisik budaya Betawi pada bangunannya padahal area embrio merupakan area utama kampung Setu Babakan yang paling banyak dikunjungi. Dua bangunan lainnya berada di sekitar area embrio. Semakin sedikitnya bangunan dengan karakter fisik budaya Betawi asli disebabkan oleh pertimbangan biaya konstruksi, efisiensi material dan waktu, kondisi lingkungan, pengaruh budaya baru, pola hidup yang berubah, kebutuhan, dan lain-lain. Bangunan-bangunan di Kampung Setu Babakan tidak lagi hanya berfungsi sebagai hunian, namun memiliki fungsi yang beragam, seperti hunian dan warung. Hal ini disebabkan oleh kebutuhan hidup masyarakat yang bertambah menyesuaikan perkembangan zaman. 


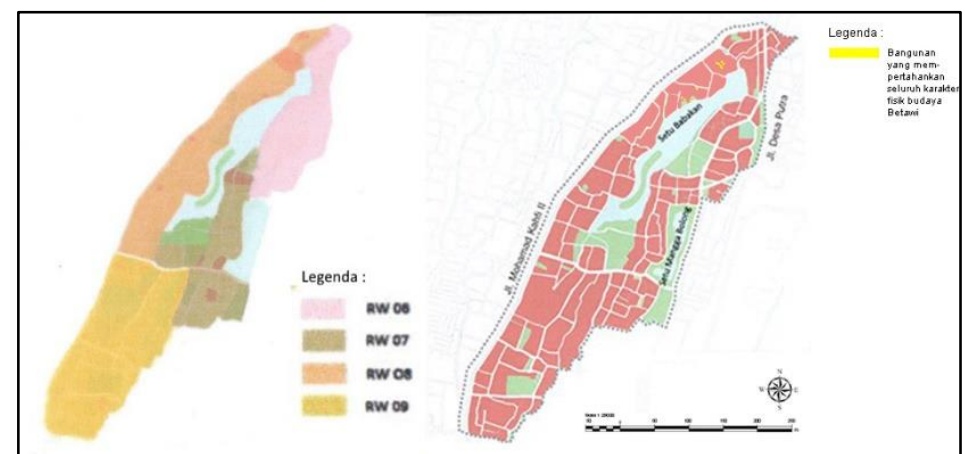

Figur 12. Pemetaan Karakter Fisik Secara Makro Yang Dipertahankan

Dari 5.961 bangunan, hanya 168 diantaranya memiliki karakter fisik budaya Betawi yang mengalami modifikasi (lihat figur 13). Karakter fisik budaya Betawi di permukiman Setu Babakan mengalami modifikasi akibat terjadinya percampuran antara budaya Betawi dengan budaya baru/budaya para pendatang. Modifikasi dilakukan sesuai dengan kebutuhan penghuni/pemilik rumah dengan pertimbangan biaya, estetika, efisiensi dan efektifitas bentuk, dan lain-lain.

Bangunan-bangunan di kampung Setu Babakan dengan karakter fisik Budaya Betawi yang mengalami modifikasi terbagi menjadi beberapa tipe yaitu: bangunan dengan karakter fisik bentuk bangunan saja (60 dari 168 bangunan); ornamen saja (30 dari 168 bangunan); elemen non-struktural saja (46 dari 168 bangunan); bentuk bangunan dan elemen nonstruktural (4 dari 168 bangunan); ornamen dan elemen non-struktural (8 dari 168 bangunan); ornamen dan tatanan ruang luar (2 dari 168 bangunan); elemen non-struktural, elemen struktural, ornamen, dan tatanan ruang luar (9 dari 168 bangunan); bentuk bangunan dan ornamen (2 dari 168 bangunan); ornamen, elemen non-struktural, dan tatanan ruang luar (5 dari 168 bangunan); bentuk bangunan, tatanan ruang luar dan ornamen (1 dari 168 bangunan); dan elemen struktural saja (1 dari 168 bangunan).

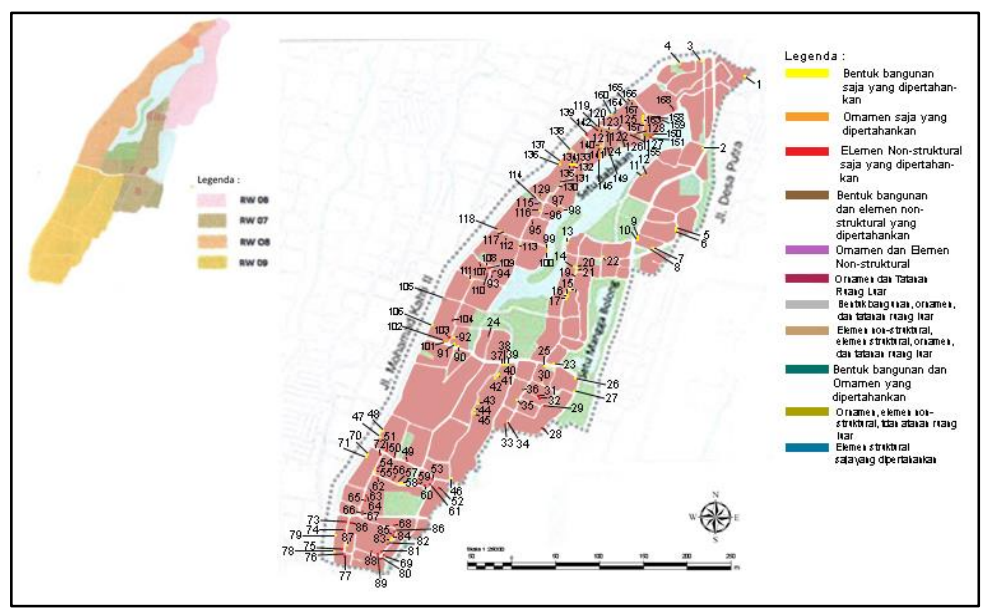

Figur 13. Pemetaan Karakter Fisik Secara Makro Yang Dimodifikasi

Karakter fisik budaya Betawi secara mikro dapat dikategorikan menjadi tiga yaitu, (1) yang masih dipertahankan karakter Betawi-nya, (2) yang mengalami modifikasi, dan (3) yang berubah secara total. Karakter fisik budaya Betawi secara mikro dilihat secara satu per satu karakter fisik Betawi, mana yang masih bertahan, yang mengalami modifikasi, atau yang berubah total, sedangkan karakter fisik budaya Betawi secara makro merupakan hasil gabungan 
dari karakter fisik secara mikro (melihat keseluruhan karakter fisik budaya Betawi per bangunan).

Karakter fisik budaya Betawi budaya Betawi terdiri dari bangunan (bentuk rumah, ornamen (lisplang), elemen struktural (kolom) dan elemen non-struktural (jendela, pintu, dan perabot), teras dan langkan) dan tatanan ruang luar (pekarangan).

Berdasarkan hasil pemetaan, bangunan-bangunan di kampung Setu Babakan terbagi menjadi yang memiliki bentuk rumah bapang/kebaya (sebanyak 477 dari 5.961 bangunan), bentuk rumah joglo (sebanyak 60 dari 5.961 bangunan), bentuk rumah kandang/gudang (sebanyak 536 dari 5.961 bangunan), bentuk rumah modern/minimalis (sebanyak 4.172 dari 5.961 bangunan), bentuk rumah bapang/kebaya yang mengalami modifikasi (sebanyak 298 dari 5.961 bangunan), bentuk rumah kandang/gudang yang mengalami modifikasi (sebanyak 358 dari 5.961 bangunan), dan bentuk rumah joglo yang mengalami modifikasi (sebanyak 59 dari 5.961 bangunan) (lihat figur 14).

Pemilihan bentuk rumah minimalis/modern adalah yang paling mendominasi di Kampung Setu Babakan karena lebih mudah pengerjaannya dan lebih efisiensi dalam hal biaya, waktu, dan ruang. Rumah modern yang cenderung sederhana/polos tidak memerlukan biaya yang lebih untuk menambah ornamen pada bangunan. Ruang-ruang di dalam bangunan juga lebih flexible karena dapat dijadikan ruangan yang multifungsi sesuai dengan kebutuhan penghuni. Rumah kandang/gudang merupakan rumah tradisional Betawi yang paling banyak dipililih, sebaliknya rumah joglo Betawi merupakan rumah tradisional Betawi yang paling sedikit dipilih karena pertimbangan tingkat kerumitan rumah joglo yang lebih tinggi dibandingkan rumah kandang/gudang.

Modifikasi yang terjadi pada bentuk rumah bapang/kebaya, bentuk rumah kandang/gudang, dan bentuk rumah joglo Betawi bervariasi, seperti perubahan proporsi bentuk bangunan, terjadinya segmentasi menjadi beberapa bangunan pada 1 atap, ketidaksimetrisan bentuk atap (rumah bapang/kebaya), mengalami substraksi, mengalami adisi, percampuran bentuk. Modifikasi tersebut disebabkan oleh beberapa faktor, seperti keterbatasan lahan, adanya penambahan ruang yang harus dinaungi akibat kebutuhan tambahan, dan pertimbangan efektivitas ruang dalam.

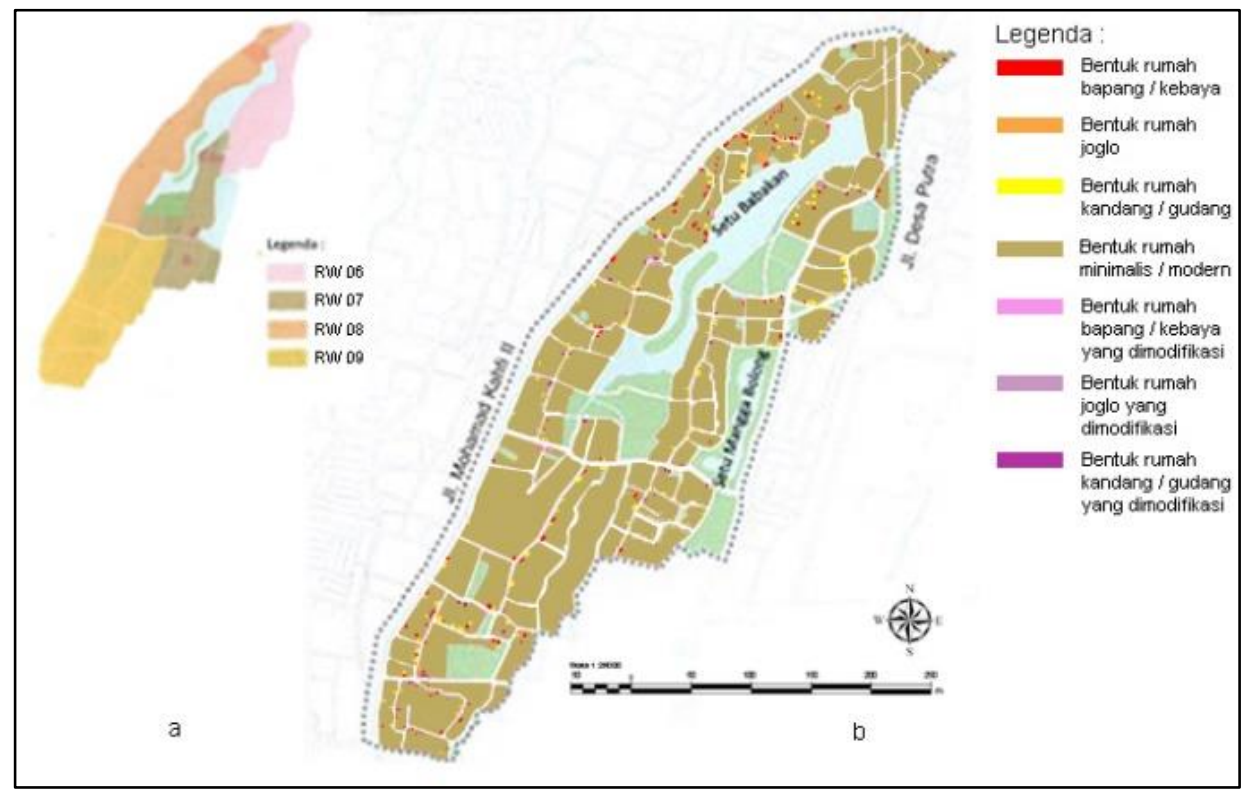

Figur 14. Pemetaan Secara Mikro Mengenai Bentuk Bangunan Di Kampung Setu Babakan 
Berdasarkan hasil pemetaan, hanya terdapat sekitar 298 dari 5.961 bangunan di kampung Setu Babakan yang menggunakan kolom/tiang khas Betawi sebagai tiang penyangga (pada teras) dan tiang utama (pada bagian utama bangunan), sebanyak 5.067 dari 5.961 bangunan yang menggunakan kolom modern/minimalis/polos, dan 596 dari 5.961 bangunan yang menggunakan kolom campuran khas Betawi dan modern (lihat figur 15). Kolom khas Betawi dan kolom campuran hanya terdapat pada teras saja, kolom di dalam rumah sudah menggunakan kolom modern/polos untuk mengurangi biaya konstruksi dan waktu pengerjaan. Terdapatnya kolom campuran disebabkan oleh adanya percampuran budaya Betawi dan budaya modern. Terjadi penyesuaian antara gaya bangunan dengan struktur bangunan agar senada dan jika ada perbedaan gaya juga perbedaannya tidak terlalu kontras agar tidak merusak tampilan bangunan. Kolom campuran pada bangunan-bangunan di Setu Babakan terbagi menjadi kolom berbentuk bulat dan persegi. Masing-masing terbagi lagi menjadi yang memiliki takik vertikal, yang memiliki kepala, yang memiliki pilaster kaki kolom, dan campuran. Selain itu, ada yang dalam 1 kolom terdiri dari 2 bentuk (kaki kolomnya kotak tetapi badan kolomnya bulat). Ada pula yang menggunakan kolom polos/minimalis/modern di lantai 2 (teras dan di dalam bangunan) dan menggunakan kolom campuran di lantai 1 (hanya di teras). Terdapat pula yang di terasnya tidak terdapat tiang karena teritis atap rumah tidak terlalu panjang. Ini disebabkan karena kolom di dalam rumah masih kuat untuk menopang bagian atap yang menaungi teras.

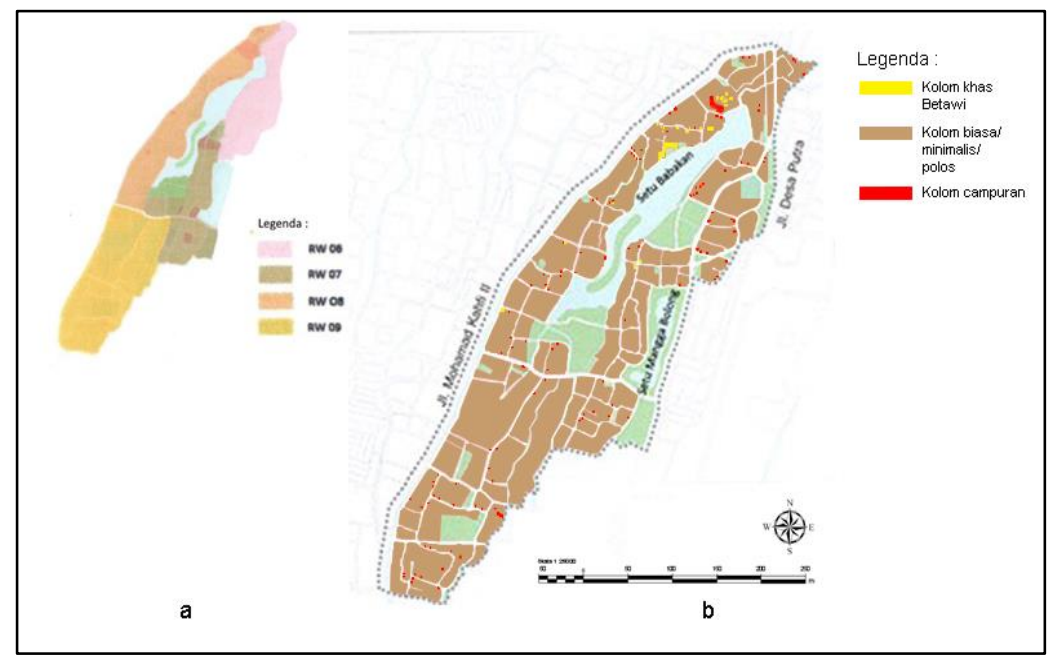

Figur 15. Pemetaan Secara Mikro Mengenai Kolom Bangunan Di Kampung Setu Babakan

Berdasarkan hasil pemetaan, hanya sekitar 298 dari 5.961 bangunan yang memiliki teras dengan dilengkapi langkan, sekitar 2.980 dari 5.961 bangunan yang memiliki teras tanpa langkan, dan sekitar 2.683 dari 5.961 bangunan yang tidak memiliki teras (lihat figur 16). Teras-teras yang terdapat pada bangunan ada yang sempit dan ada yang luas. Teras-teras tersebut juga ada yang dialihfungsikan dan dimultifungsikan menjadi tempat jemuran, tempat memarkir motor, dan atau berdagang. Tidak terdapatnya teras, teras yang sempit, dan dimanfaatkannya teras menjadi multifungsi disebabkan oleh masalah keterbatasan lahan. Pertumbuhan penduduk yang pesat di perkotaan menyebabkan lahan kosong semakin berkurang dan berakibat pada harga lahan yang semakin mahal, sehingga pembagian lahan dilakukan agar harga lahan tidak terlalu mahal dan akibatnya semakin banyak jumlah lahan yang sempit di perkotaan. Tidak terdapatnya langkan disebabkan oleh sudah terdapatnya pagar pembatas antara pekarangan dengan jalan. 


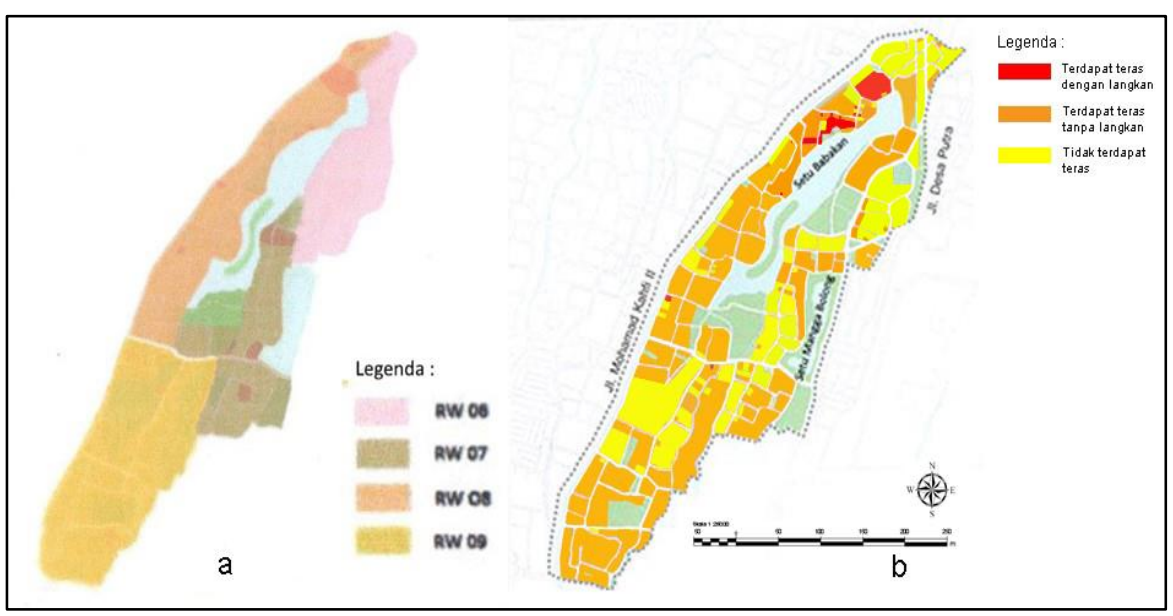

Figur 16. Pemetaan Secara Mikro Mengenai Teras dan Langkan Bangunan Di Kampung Setu Babakan

Berdasarkan hasil pemetaan, hanya terdapat sekitar 358 dari 5.961 bangunan di kampung Setu Babakan yang memiliki jendela khas Betawi. Jendela biasa/minimalis/modern sebanyak 5.365 dari 5.961 bangunan, dan sebanyak 238 dari 5.961 bangunan lainnya memiliki jendela campuran (lihat figur 17). Jendela bujang sudah tidak ditemukan di permukiman Setu Babakan (baik yang jendela khas Betawi maupun jendela campuran). Jendela modern (jendela kaca) lebih banyak digunakan oleh masyarakat karena jendela kaca memperkuat interaksi antara ruang luar dan ruang dalam dan dapat meningkatkan kedekatan masyarakat dengan alam. Masyarakat zaman sekarang memiliki tingkat stress yang tinggi karena tuntutan kerja, kesibukan sehari-hari, dan faktor lainnya, sehingga memerlukan interaksi dengan ruang luar dan kedekatan dengan alam yang dapat memberikan ketenangan hidup dan menghilangkan stress. Selain itu, pembuatan jendela modern juga lebih mudah dibandingkan pembuatan jendela krepyak khas Betawi karena bentuknya yang sederhana lebih (hanya kaca dengan frame kusen).

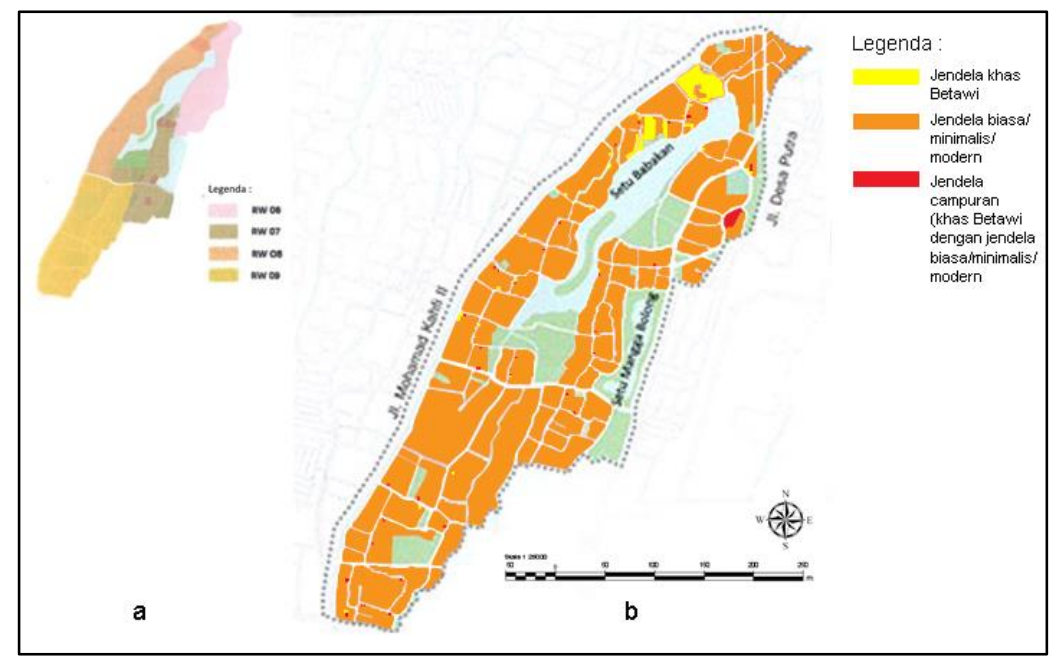

Figur 17. Pemetaan Secara Mikro Mengenai Jendela Bangunan Di Kampung Setu Babakan

Berdasarkan hasil pemetaan, hanya terdapat sekitar 298 dari 5.961 bangunan di kampung Setu Babakan yang memiliki pintu khas Betawi dengan lubang ventilasi udara yang juga khas Betawi di atasnya, terutama pada pintu utama bangunan, terdapat sekitar 119 dari 5.961 bangunan yang memiliki pintu khas Betawi tanpa lubang ventilasi di atasnya, sebanyak 4.352 dari 5.961 bangunan memiliki pintu modern/minimalis/polos tanpa lubang ventilasi diatasnya, 
dan 1.192 dari 5.961 bangunan lainnya menggunakan pintu modern/minimalis/polos dengan lubang ventilasi di atasnya (lihat figur 18). Ventilasi udara dibutuhkan bukan hanya dari jendela dan diatas jendela, namun juga dari atas pintu karena di masa lampau tidak terdapat pendingin buatan di dalam rumah, sedangkan rumah cukup luas sehingga memerlukan pertukaran udara yang baik dan banyak. Begitu pula pada rumah-rumah warga di kampung Setu Babakan yang memiliki lubang ventilasi di atas pintu maupun jendela. Hal ini dikarenakan di dalam rumah tidak menggunakan pendingin buatan untuk meminimalisir biaya listrik. Pintu khas Betawi yang digunakan kebanyakan berbentuk krepyak dan panil kayu yang terdapat takikan di sudutsudutnya. Krepyak sebagai bagian dari daun pintu juga dapat menjadi ventilasi udara. Pemilihan pintu modern/minimalis/polos lebih banyak digunakan karena lebih sederhana dan mudah pengerjaannya.

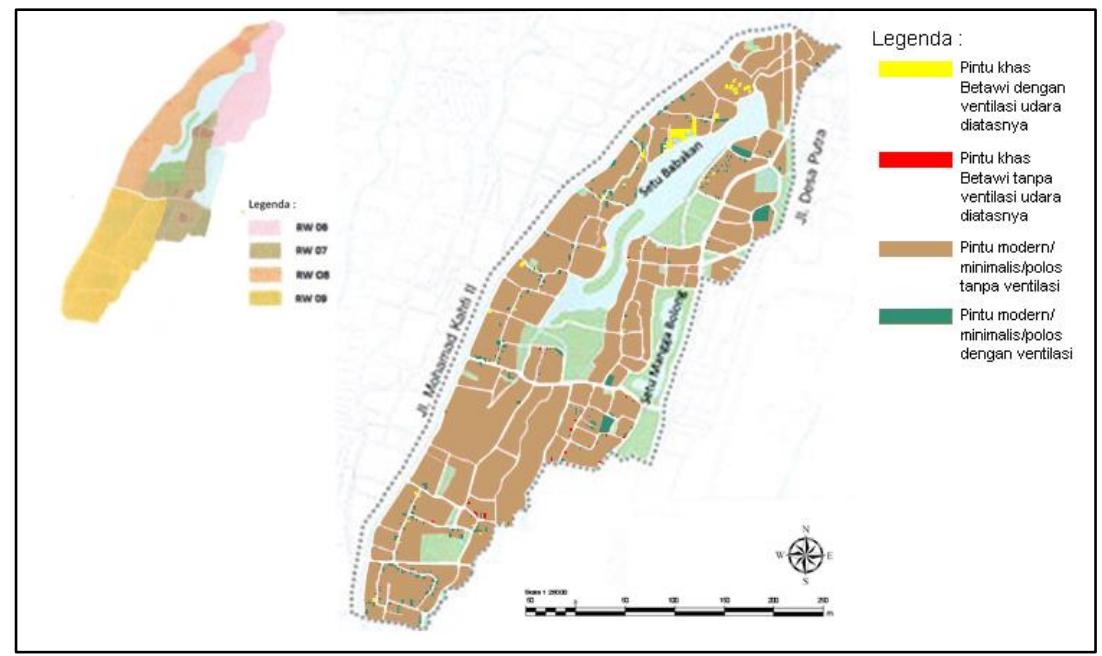

Figur 18. Pemetaan Secara Mikro Mengenai Pintu Bangunan Di Kampung Setu Babakan

Berdasarkan hasil pemetaan, hanya terdapat sekitar 298 dari 5.961 bangunan di kampung Setu Babakan yang memiliki perabot khas Betawi pada terasnya, terdapat sekitar 1.490 dari 5.961 bangunan memiliki perabot modern/minimalis, dan sekitar 4.173 dari 5.961 bangunan lainnya tidak memiliki perabot pada terasnya (lihat figur 19). Perabot khas Betawi yang berada di teras warga umumnya tidak lengkap seperti yang terdapat di teras rumah tradisinal Betawi. Ada yang hanya memiliki 2 kursi dan 1 meja khas betawi, ada yang hanya memiliki 2-4 kursi khas Betawi pada terasnya, ada yang hanya memiliki bale-bale. Hanya pada beberapa rumah di RW 08 (area embrio) yang masih memiliki perabot selengkap yang terdapat di teras rumah tradisional Betawi ( 2 meja dan 8 kursi yang terbagi menjadi 2 set yang mejanya juga hanya 1 jenis (kedua mejanya bulat atau kedua mejanya persegi), lampu gantung khas Betawi dan balebale). Pada rumah-rumah tersebut, area teras masih sering digunakan untuk berkumpul dan bersantai bersama keluarga dan warga setempat, sehingga perabot-perabot pada teras tersebut memang diperlukan oleh pemilik rumah. Lahan yang luas memungkinkan rumah memiliki teras yang luas dan diisi banyak perabot.

Kebanyakan bangunan menggunakan perabot modern karena lebih murah akibat pembuatannya yang lebih mudah (tidak ada ukiran) dan bahannya yang lebih mudah ditemukan (misalnya plastik, besi, dan padded panel). Semakin banyaknya pabrikasi perabot modern juga menjadi pertimbangan karena lebih mudah dicari.

Tidak terdapatnya perabot teras disebabkan oleh sempitnya teras akibat keterbatasan lahan serta teras yang dimanfaatkan menjadi fungsi lain (tidak lagi sebagai tempat untuk bersantai/duduk-duduk) seperti tempat untuk menjemur pakaian dan memarkir motor. 


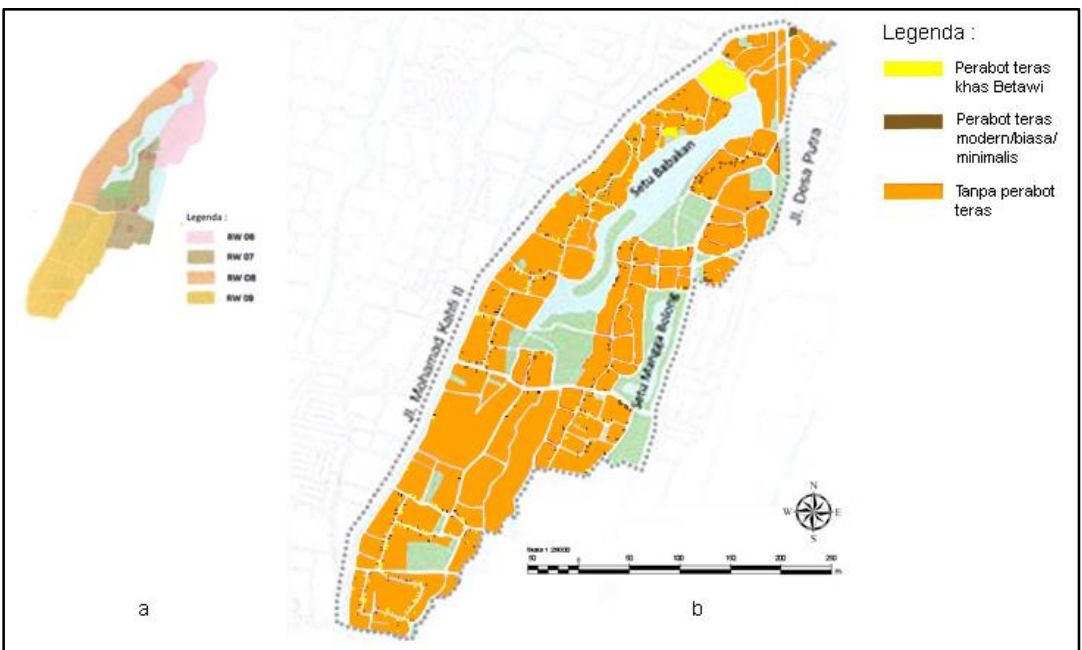

Figur 19. Pemetaan Secara Mikro Mengenai Perabot Teras Bangunan Di Kampung Setu Babakan

Berdasarkan hasil pemetaan, terdapat sekitar 1.192 dari 5.961 bangunan di kampung Setu Babakan yang memiliki lisplang khas Betawi dan 4.769 dari 5.961 bangunan lainnya menggunakan lisplang polos (lihat figur 20). Lisplang Betawi yang diterapkan di permukiman Setu Babakan ada yang berupa ukiran (berfungsi sebagai penutup struktur atap agar terlihat lebih rapih dan sebagai ornamen estetik yang menunjukkan karakter budaya Betawi), ada yang berupa ukiran yang tertempel di lisplang yang polos (hanya berfungsi sebagai ornamen estetik saja). Adanya teknik pengukiran lisplang baru tersebut (ukiran gigi balang yang tretempel pada lisplang polos) dipengaruhi oleh perkembangan teknologi.

Selain diterapkan pada rumah Betawi, lisplang gigi balang juga ada yang diterapkan pada rumah modern. Namun, lisplang yang diterapkan pada bentuk atap modern menyebabkan kesan khas Betawi menjadi tidak terasa (walaupun memiliki lisplang gigi balang) karena lisplang hanya terdapat pada sebagian kecil bagian bangunan, serta atap dan lisplang merupakan satu kesatuan yang menunjukkan ciri khas Betawi.

Lisplang yang polos tidak hanya digunakan pada rumah-rumah bergaya modern, tetapi juga digunakan pada beberapa rumah Betawi. Pertimbangan ekonomi menjadi salah satu alasan masyarakat tidak memasang lisplang gigi balang di rumahnya. Lisplang yang diukir lebih mahal daripada lisplang yang polos (sebanding dengan tingkat kerumitannya). Selain itu, lisplang yang diukir juga lebih mudah berdebu, kotor, dsb karena terdapat lekukan-lekukan dan lubang kecil. Terdapatnya lubang dan lekukan juga menyebabkan bidang lisplang lebih rentan untuk patah daripada bidang yang utuh seperti lisplang polos (dengan material dan ketebalan yang sama). 


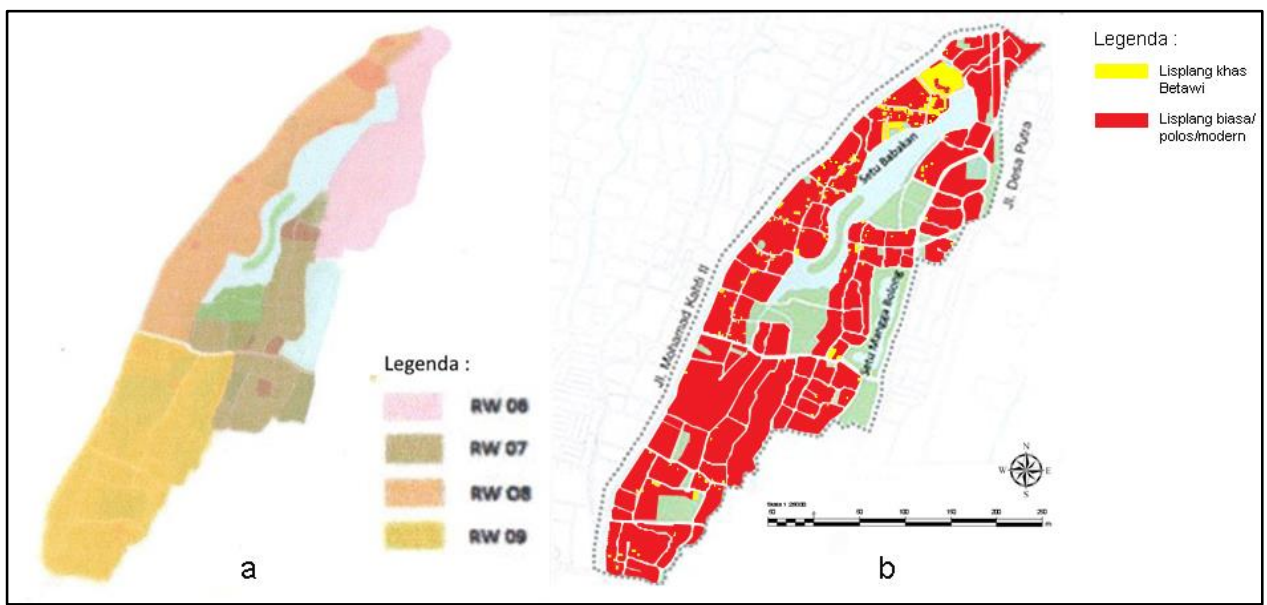

Figur 20. Pemetaan Secara Mikro Mengenai Lisplang Bangunan Di Kampung Setu Babakan

Diperlukan pekarangan yang luas karena pekarangan berfungsi sebagai tempat untuk mengadakan palang pintu saat acara pernikahan, sebagai kebun yang sekaligus taman untuk menambah penghasilan sehari-hari dari hasil kebun, sebagai tempat jemuran, tempat untuk parkir mobil/motor, pendopo, ruang terbuka biru/kolam, area untuk menyimpan meja/gerobak dagangan, dan tanahnya/lahannya dapat dibagi-bagi kepada anak cucunya sebagai warisan kelak. Masyarakat Betawi di masa lampau juga memanfaatkan pekarangan sebagai tempat untuk menaruh lumbung padi serta kandang ternak, namun lumbung padi dan kendang ternak sudah tidak ditemukan di pekarangan rumah warga kampung Setu Babakan. Hal ini disebabkan oleh beberapa faktor seperti sempitnya lahan, warga yang berprofesi sebagai petani cenderung menaruh lembung padi serta alat-alatnya di dalam rumah agar tidak hilang (pola pikir masyarakat saat ini yang menganggap keamanan kota menurun).

Untuk upacara adat, sebagian besar warga yang beretnis Betawi masih menjalankan sesuai dengan adat Betawi hanya saja ada yang tidak lengkap prosesnya karena pengaruh biaya. Hal ini dapat dibuktikan dengan masih adanya ondel-ondel dan pakaian-pakaian adat yang digunakan saat upacara adat, dan adanya pelatihan pencak silat yang digunakan pada saat acara pernikahan. Sehingga, ruang terbuka non-hijau dan halaman rumah yang luas masih digunakan sebagai wadah upacara adat.

Berdasarkan hasil pemetaan, di kampung Setu Babakan memiliki pekarangan yang luas sebanyak 2.563 dari 5.961 bangunan (keseluruhan kawasan), sebanyak 2.563 dari 5.961 bangunan memiliki pekarangan yang sempit, dan sebanyak 835 dari 5.961 bangunan lainnya tidak memiliki pekarangan (lihat figur 21). Dari $43 \%$ pekarangan yang sempit, terdapat beberapa diantaranya yang tidak memiliki teras. Terdapatnya pekarangan yang luas dapat terwujud karena masih terdapat sebagian warga yang lahannya belum terbagi-bagi dan masih terdapat kebun milik warga (terutama bagi warga yang mata pencahariannya sebagai petani). Terdapatnya pekarangan yang sempit disebabkan oleh lahan/kavling yang tidak terlalu luas sehingga sisa lahan setelah membangun rumah menjadi sedikit. Terdapat banyak lahan/kavling yang tidak terlalu luas di perkotaan, khusunya untuk permukiman disebabkan oleh lahan kosong yang ada tidak cukup untuk memenuhi kebutuhan hunian yang semakin lama semakin banyak akibat pesatnya pertumbuhan penduduk, urbanisasi, dan migrasi, sehingga hampir semua lahan yang luas dibagi-bagi menjadi beberapa lahan yang tidak terlalu luas/sempit untuk diperjual belikan.

Terdapatnya rumah yang tidak memiliki pekarangan/halaman disebabkan oleh tanah yang sempit tidak dapat memenuhi seluruh kebutuhan ruang yang diperlukan pemilik/penghuni rumah, sehingga perlu ada area yang dikorbankan. Sebagian masyarakat menganggap bahwa ruang dalam rumah lebih penting dari ruang luar karena aktivitas masyarakat tersebut lebih 
banyak dilakukan di dalam rumah, sehingga ruang luar menjadi dikorbankan. Tingkat keamanan kota yang semakin lama semakin menurun, polusi udara, panasnya suhu di luar rumah akibat ruang terbuka hijau yang semakin sedikit menjadi alasan aktivitas masyarakat tersebut lebih banyak dilakukan di dalam rumah (ruang dalam rumah dianggap lebih aman dan nyaman untuk menghabiskan waktu dan melakukan aktivitas sehari-hari).

Selain itu, terdapat rumah tanpa pekarangan tetapi memiliki teras yang luas. Hal ini disebabkan oleh pemikiran pemilik rumah yang mengutamakan keberadaan teras yang besar dan mengorbankan keberadaan pekarangan karena pemilik rumah merasa nyaman untuk bersantai-santai di teras yang luas bersama keluarga. Pemilik rumah menganggap teras juga dapat difungsikan sebagai tempat untuk menjemur pakaian dan atau tempat untuk memarkir motor bila diperlukan. Namun, dengan tidak adanya pekarangan, rumah tersebut menjadi tidak ada ruang terbuka hijau/kebun/taman.

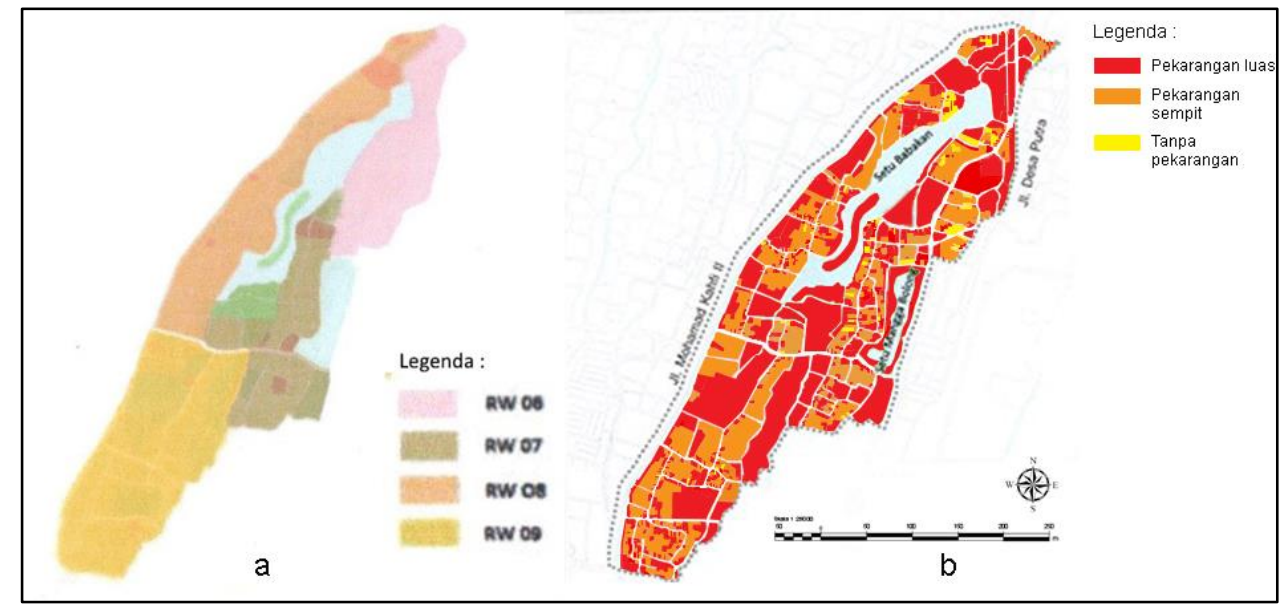

Figur 21. Pemetaan Secara Mikro Mengenai Pekarangan Di Kampung Setu Babakan

\section{KESIMPULAN}

Hasil pemetaan dan analisis karakter fisik secara makro yang dipertahankan menunjukkan bahwa hanya 10 bangunan dari 5.961 bangunan yang masih dapat mencerminkan karakter fisik budaya Betawi secara utuh. Hal ini disebabkan oleh beberapa faktor, seperti adanya budaya baru akibat perkembangan zaman ataupun budaya dari pendatang, gaya hidup dan keadaan lingkungan yang berubah, keterbatasan lahan, faktor ekonomi, perkembangan teknologi dan bahan, dan lain-lain.

Hasil pemetaan dan analisis karakter fisik secara makro yang dimodifikasi menghasilkan adanya 11 tipe modifikasi bangunan yaitu, (1) Bentuk bangunan saja yang dipertahankan, (2) Ornamen saja yang dipertahankan, (3) Elemen non-struktural saja yang dipertahankan, (4) Bentuk bangunan dan elemen non-struktural yang dipertahankan, (5) Ornamen dan elemen non-struktural yang dipertahankan, (6) Ornamen dan tatanan ruang luar yang dipertahankan, (7) Elemen non-struktural, elemen struktural, ornamen, dan tatanan ruang luar yang dipertahankan, (8) Bentuk bangunan dan ornamen yang dipertahankan, (9) Ornamen, elemen non-struktural, dan tatanan ruang luar yang dipertahankan, (10) Bentuk bangunan, tatanan ruang luar, dan ornamen yang dipertahankan, dan (11) Elemen struktural saja yang dipertahankan.

Jumlah yang paling banyak adalah tipe dengan bentuk bangunan saja yang dipertahankan. Jumlah yang paling sedikit adalah tipe dengan bentuk bangunan, tatanan ruang 
luar, dan ornamen yang dipertahankan dan tipe dengan elemen struktural saja yang dipertahankan juga memiliki jumlah yang paling sedikit.

Hasil pemetaan dan analisis karakter fisik secara mikro menunjukkan bahwa setiap karakter fisik khas Betawi sudah sedikit diterapkan (dibawah 50\%) pada bangunan-bangunan di permukiman Setu Babakan. Karakter fisik tersebut ada yang mengalami modifikasi, seperti, (1) Bangunan dan (2) Ruang luar.

1. Bangunan

a. Pada bentuk bangunan, terjadi substraksi/adisi/percampuran antar bentuk/berubah proporsi;

b. Pada elemen struktural (kolom), terjadi percampuran gaya modern dan gaya Betawi;

c. Pada teras dan langkan, terdapat beberapa rumah yang tidak memiliki teras/memiliki teras tetapi tanpa langkan;

d. Pada elemen non-struktural (jendela, pintu, perabot teras), untuk jendela dan pintu, terjadi percampuran antara gaya modern dan gaya Betawi, untuk perabot teras, terjadi perubahan jumlah perabot dan ada pula yang tidak memiliki perabot teras;

e. Pada ornamen (lisplang), tidak terjadi modifikasi tetapi ada yang berubah total menjadi gaya modern (lisplang polos).

2. Ruang Luar

a. Pada pekarangan, terjadi perubaan pada luas dan elemen pelingkupnya (dari yang dibatasi dengan pohon tinggi, menjadi dibatasi dengan pagar).

Hal ini disebabkan oleh beberapa faktor, seperti adanya budaya baru akibat perkembangan zaman ataupun budaya dari pendatang, gaya hidup dan keadaan lingkungan yang berubah, keterbatasan lahan, faktor ekonomi, perkembangan teknologi dan bahan, dan lain-lain. Hasil penelitian menunjukkan perlunya kawasan Kampung Setu Babakan untuk dikembangkan lebih optimal, terutama pada karakter fisik budaya Betawinya.

\section{DAFTAR PUSTAKA}

AMAL, M. Ichlasul. 1999. Perkembangan Arsitektur Rumah Tinggal Betawi. Disertasi tidak diterbitkan. Bandung: Universitas Katolik Parahyangan.

DR. ARIE BUDHIMAN, M.SI. 2012. Kajian Pengembangan Ornamen Betawi. Jakarta: Dinas Pariwisata dan Kebudayaan Provinsi DKI Jakarta.

INDONESIA. Kantor Pengelola Setu Babakan. 2016. Paparan Perencanaan Perkampungan Budaya Betawi Setu Babakan Jakarta Selatan. Jakarta: Disertasi tidak diterbitkan.

ISMET B. HARUN, K. HISMAN. 1991. Rumah Tradisional Betawi. Jakarta: Dinas Kebudayaan Daerah Khusus Ibukota Jakarta.

PEMERINTAH DAERAH. 2017. Pelestarian Kebudayaan Betawi. Jakarta: Dewan Pengurus Badan Musyawarah Masyarakat Betawi [BAMUS BETAWI].

SAFARI. 2016. Budaya Betawi Nyaris Musnah, Pemerintah Ditunding Lakukan Genoside.

[Online]. Available:

http://megapolitan.harianterbit.com/megapol/2016/04/08/59698/18/18/Budaya

Betawi-Nyaris-Musnah-Pemerintah-Dituding-Lakukan-Genoside. [25 Mei 2018] 